\title{
Screening and identification of apolipoprotein A-I as a potential hepatoblastoma biomarker in children, excluding inflammatory factors
}

\author{
WEI ZHAO ${ }^{1}$, JUAN LI ${ }^{2}$, YILIN ZHANG ${ }^{3}$, PENGFEI GAO ${ }^{1}$, \\ JUNJIE ZHANG $^{1}$, FEI GUO ${ }^{1}$, JIEKAI YU ${ }^{4}$, SHU ZHENG ${ }^{4}$ and JIAXIANG WANG ${ }^{1}$ \\ Departments of ${ }^{1}$ Pediatric Surgery and ${ }^{2}$ Respiratory Medicine, The First Affiliated Hospital of Zhengzhou University, \\ Zhengzhou, Henan 450052; ${ }^{3}$ Department of Clinical Medicine, Basic Medical College of Zhengzhou University, Zhengzhou, \\ Henan 450001; ${ }^{4}$ Institute of Cancer, The Second Affiliated Hospital, College of Medicine, \\ Zhejiang University, Hangzhou, Zhejiang 310009, P.R. China
}

Received July 25, 2014; Accepted April 21, 2015

DOI: $10.3892 / \mathrm{ol} .2015 .3207$

\begin{abstract}
The aim of the present study was to identify a child hepatoblastoma serum biomarker that is unaffected by inflammatory factors, with the ultimate aim of finding an effective method for the early diagnosis of hepatoblastoma. The magnetic bead-based weak cation exchange chromatography technique was used to process serum harvested from 30 children with hepatoblastoma, 20 children with systemic inflammatory response syndrome (SIRS) and 20 healthy children. Proteins differentially expressed in SIRS were excluded from consideration as biomarkers for hepatoblastoma. Proteins differentially expressed in hepatoblastoma and healthy controls were screened using surface-enhanced laser desorption/ionization-time of flight-mass spectrometry (SELDI-TOF-MS). Target proteins were purified by SDS-PAGE, and matrix-assisted laser desorption/ionization (MALDI)-TOF-MS was used to determine their amino acid sequences. Protein matches were searched in the SwissProt database. Quantitative polymerase chain reaction (qPCR) and ELISA were employed to confirm the expression of target proteins. Following screening to exclude inflammatory factors, SELDI-TOF-MS revealed a protein with a mass-to-charge ratio of 9,348 $\mathrm{Da}$ that was expressed at significantly lower levels in the serum of children with hepatoblastoma compared with healthy controls $(\mathrm{P}<0.01)$. Sequence analysis identified this protein as apolipoprotein A-1 (Apo A-I). qPCR and ELISA confirmed that the expression of Apo A-I mRNA and
\end{abstract}

Correspondence to: Professor Jiaxiang Wang, Department of Pediatric Surgery, The First Affiliated Hospital of Zhengzhou University, 1 East Jianshe Road, Zhengzhou, Henan 450052, P.R. China

E-mail: wjiaxiang@zzu.edu.cn

Key words: hepatoblastoma, MALDI-TOF-MS, Apo A-I, proteomics, biomarker protein were significantly lower in children with hepatoblastoma compared with healthy controls $(\mathrm{P}<0.05)$. These results indicate that Apo A-I is a non-inflammatory protein marker for hepatoblastoma with the potential for use in early diagnosis of hepatoblastoma. In addition, the present study demonstrates the feasibility of proteomic screening for the identification of proteins that can serve as markers for a specific tumor.

\section{Introduction}

Hepatoblastoma is a common liver malignancy in children, with an incidence ranking third among abdominal solid tumors in children. This disease is often observed in boys aged between 6 months and 3 years and is rarely diagnosed in adults. Annually, 0.5-1.5 children per million are diagnosed with hepatoblastoma, accounting for $1 \%$ of malignancies in children and 50-79\% of liver malignancies in children (1). Hepatoblastoma is a curable malignancy in children and early diagnosis and therapy are effective in increasing survival rates (2). However, this type of cancer grows rapidly and has no specific clinical manifestations. Children with hepatoblastoma often present initially with a giant mass in the abdominal cavity, when the hepatoblastoma is at stage II or higher, and with metastases to the porta hepatis, portal vein or brain (3), leading to a poor prognosis. Color Doppler ultrasound, CT and hepatic arteriography are routinely used to diagnose hepatoblastoma, but these modalities are less effective for early diagnosis (4). Thus, the development of novel diagnostic methods is necessary for the early diagnosis of hepatoblastoma.

Proteomics has been used previously in the field of oncology to identify tumor-associated markers for the early diagnosis of cancer, to investigate mechanisms of pathogenesis and to identify therapeutic targets $(5,6)$. Biomarkers have been identified for a variety of tumor types (7-9), including nephroblastoma (10-12), ovarian (13), prostate (14), pancreatic (15), colon (16) and breast cancer (17). The expression of certain serum proteins may be altered in patients with cancer due to focal or systemic inflammation; these proteins or inflammatory 
factors may confound biomarker screening for malignancies in these patients (18). Thus, these inflammation-associated proteins must be excluded when screening for biomarkers specific to malignancies.

The present study aimed to identify a pediatric hepatoblastoma serum biomarker that is unaffected by inflammatory factors. Serum was harvested from healthy children and those with hepatoblastoma or systemic inflammatory response syndrome (SIRS). A serum marker for hepatoblastoma was screened and identified following the exclusion of interfering inflammatory factors.

\section{Materials and methods}

Clinical information. Participants were recruited from the First Affiliated Hospital of Zhengzhou University of Henan Province (Zhengzhou, China) between December 2011 and December 2013. There were 30 children with pathologically proven hepatoblastoma, including 19 males and 11 females, with a mean age of 39.80 \pm 16.50 months (range, 2-70 months). There were 20 children with SIRS, including 12 male and 8 female, with a mean age of $47.26 \pm 19.76$ months (range, 6-84 months). In addition, 20 healthy children were recruited as controls, including 10 males and 10 females, with a mean age of $38.53 \pm 18.46$ months (range, 6-72 months). Fasting blood was harvested from these subjects in the morning (05:00-06:00) and placed at room temperature for $1 \mathrm{~h}$, followed by centrifugation at $3,000 \mathrm{x}$ g for $20 \mathrm{~min}$. Supernatants were collected and stored at $-80^{\circ} \mathrm{C}$. Prior to the study, informed consent was obtained from the parents of these children. The study was approved by the ethics committee of Zhengzhou University.

Screening of differentially expressed proteins in the serum using SELDI-TOF-MS. Frozen sera were thawed in cold water, centrifuged at $10,000 \mathrm{xg}$ for $5 \mathrm{~min}$ at $4^{\circ} \mathrm{C}$ and the supernatants were collected. MB-WCX binding buffer $(10 \mu \mathrm{l})$, MB-WCX magnetic beads $(10 \mu \mathrm{l})$ (Profiling Kit $100 \mathrm{MB}-\mathrm{WCX}$, Bruker Corporation, Ettlingen, Germany), and serum (5 $\mu \mathrm{l})$ were mixed in an eppendorf tube and incubated at room temperature for $5 \mathrm{~min}$. The tube was then placed in a bead separator for $1 \mathrm{~min}$. The solution (but not beads) was removed, and the beads were washed twice with $100 \mu \mathrm{l}$ MB-WCX wash buffer. The solution was removed, and $5 \mu$ l MB-WCX elution buffer was added. The tube was then placed into a bead separator for $2 \mathrm{~min}$. The supernatant was transferred to a $0.5-\mathrm{ml}$ tube, to which $5 \mu 1$ MB-WCX stabilization buffer was added, followed by mass spectrometry (MS) analysis.

The parameters for Ciphergen PBS II+ SELDI-TOF-MS (Bio-Rad Laboratories, Inc., Hercules, CA, USA) were set as follows: Maximal molecular weight, 30,000 Da (optimal molecular weight, 2,000-20,000 Da); optimal laser intensity, 190; and optimal sensitivity, 7. The extracted proteins were added to a Ciphergen WCX2 protein chip (Bio-Rad Laboratories, Inc.) that was placed in the instrument for analysis. Following bioprocessor analysis, different protein peaks and the corresponding mass-to-charge ratios $(\mathrm{m} / \mathrm{z})$ were further analyzed; peaks with a difference in $\mathrm{m} / \mathrm{z}$ of $<0.3 \%$ were regarded as representing the same protein. The data were analyzed using the Wilcoxon rank sum test, and the proteins differentially expressed between healthy children and those with hepatoblastoma were identified based on the protein peaks and the corresponding $\mathrm{m} / \mathrm{z}$. The proteins differentially expressed between healthy children and those with SIRS (inflammatory proteins) were identified based on protein peaks and the corresponding $\mathrm{m} / \mathrm{z}$. These proteins were then excluded from those with potential as biomarkers during comparison of the protein expression between healthy children and those with hepatoblastoma.

Identification of target proteins by MALDI-TOF-MS. Serum proteins ( $5 \mu \mathrm{l} /$ lane) were separated by SDS-PAGE on a separation gel with $12 \%$ acrylamide bis and a stacking gel of $5 \%$ acrylamide bis (10x Tris/Glycine/SDS, pH 8.8, Bio-Rad Laboratories, Inc.) at a voltage of $30 \mathrm{~V}$ through the separation gel and at $90 \mathrm{~V}$ through the stacking gel. The gels were then stained with Coomassie brilliant blue (Bio-Rad Laboratories, Inc.). The target protein bands were cut from the gel and stored at $-20^{\circ} \mathrm{C}$ for further identification. Gel slices containing the target proteins were placed in , $80 \mu \mathrm{l}$ wash buffer (acetonitrile, Sangon Biotech Co. Ltd., Shanghai, China), centrifuged at $10,000 \mathrm{x} \mathrm{g}$ at $37^{\circ} \mathrm{C}$ for $3-5 \mathrm{~min} 3$ times, and dried at $90^{\circ} \mathrm{C}$ for $15 \mathrm{~min}$. A total of $20 \mu \mathrm{l}$ of digest buffer [Dithiothreitol (10 mmol/l) / $\mathrm{NH}_{4} \mathrm{HCO}_{3}$ (100 mmol/l), Sigma-Aldrich, St. Louis, MO, USA] and $2 \mu \mathrm{l}$ reducing agent [iodoacetamide $(55 \mathrm{mmol} / \mathrm{l}) / \mathrm{NH}_{4} \mathrm{HCO}_{3}(100 \mathrm{mmol} / \mathrm{l})(2 \mu \mathrm{l})$, Sigma-Aldrich] were added to the dried proteins, followed by incubation at $37^{\circ} \mathrm{C}$ for $10 \mathrm{~min}$. After cooling to room temperature, $2 \mu \mathrm{l}$ blocking agent $\left[\mathrm{NH}_{4} \mathrm{HCO}_{3}(20 \mathrm{mmol} / \mathrm{l})\right.$, Sangon Biotech Co. Ltd.] and $0.5 \mu \mathrm{l}$ diluted trypsin were added. The mixture was incubated at $37^{\circ} \mathrm{C}$ with constant vortexing, followed by centrifugation at $10,000 \mathrm{x} \mathrm{g}$ at $4^{\circ} \mathrm{C}$ for $10 \mathrm{~min}$. The supernatants were transferred to fresh tubes to which $0.1 \%$ formic acid $(0.2 \mu \mathrm{l})$ and $50 \%$ acetonitrile $(0.2 \mu \mathrm{l})$ were added. Following centrifugation at $10,000 \mathrm{x}$ g for $10-15 \mathrm{~min}$. Next, the supernatants were harvested for identification of proteins.

Nano high-performance liquid chromatography was used to purify supernatant proteins for application to a protein chip, which was then loaded into the MALDI-TOF-MS instrument (Bruker Corporation). Peptides were identified following protein digestion. Mascot searching software (www.matrixscience.com/, Matrix Science Inc., Boston, MA, USA) was used to search for corresponding proteins in the SwissProt database (www.expasy.org/proteomics).

Confirmation of target protein expression using quantitative polymerase chain reaction $(q P C R)$. The Whole Blood RNA Purification Mini kit (Thermo Fisher Scientific, Inc., Waltham, MA, USA) was used to extract total RNA from the serum of children with hepatoblastoma and healthy controls. To detect the mRNA expression of target proteins, first-strand cDNA was synthesized from RNA using the Revert Aid First Strand cDNA Synthesis Kit (Thermo Fisher Scientific, Inc.). First-strand cDNA was amplified by qPCR using the Scientific Maxima SYBR Green qPCR Master Mix (Thermo Fisher Scientific, Inc.). The PCR primers for the amplification of the target protein apolipoprotein A-1 (Apo A-I) were produced by Sangon Biotech Co. Ltd. and the sequences were as follows: Forward, 5'-ACAGCGTGA CCTCCACCTT-3' and reverse, 5'-CTTGCTCATCTCCTG 
The peaks in group 0

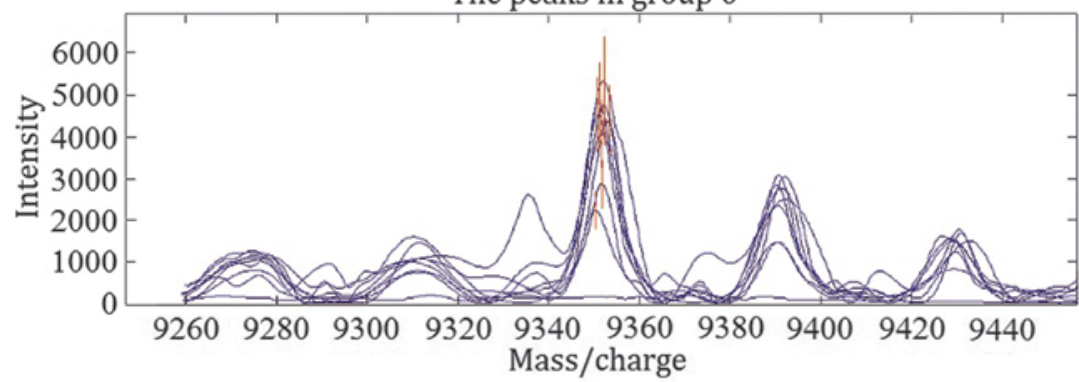

The peaks in group 1

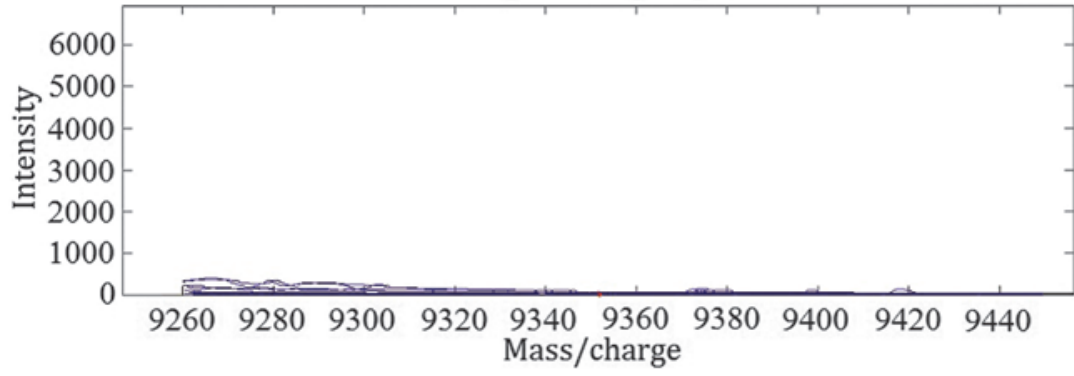

Figure 1. Screening of proteins differentially expressed between children with hepatoblastoma and healthy controls. A protein with $\mathrm{m} / \mathrm{z}$ of $9348 \mathrm{Da}$ demonstrated reduced expression in children with hepatoblastoma compared with healthy controls ( $29.0 \pm 0.9$ vs. $2036.7 \pm 881.5$, respectively; $\mathrm{P}<0.01)$. Group 0 , healthy control group; group 1, hepatoblastoma group.

CCTCA-3'. PCR was carried out as follows: Pre-treatment with uracil-DNA glycosylase (Sangon Biotech Co. Ltd.) at $50^{\circ} \mathrm{C}$ for $2 \mathrm{~min}$, pre-denaturation at $95^{\circ} \mathrm{C}$ for $10 \mathrm{~min}$, 40 cycles of denaturation at $95^{\circ} \mathrm{C}$ for $15 \mathrm{sec}$, annealing at $60^{\circ} \mathrm{C}$ for $30 \mathrm{sec}$, and extension at $60^{\circ} \mathrm{C}$ for $30 \mathrm{sec}$. Molecular Analyst ABI 7500 Software, version 2.0.1 (Bio-Rad Laboratories, Inc.) was used to analyze the PCR products, and the target protein mRNA expression levels were normalized against $\beta$-actin.

Enzyme linked-immunosorbent assay (ELISA). ELISA was used to detect the expression of Apo A-I protein in the serum of children with hepatoblastoma and healthy controls, using a Human apoprotein A1, apo-A1 ELISA kit (Sangon Biotech Co. Ltd.). Standard Apo A-I protein solutions (0, $62.5,125,250,500,1,000,2,000$ and 4,000 pg/ml) were prepared, and triplicate 100- $\mu 1$ samples at each concentration were added to a 96-well plate coated with monoclonal rabbit anti-human Apo A-I antibody (1:100 dilution). Serum collected from children with hepatoblastoma $(n=10)$ and healthy controls $(n=10)$ was diluted $1: 100$ with the ABC working solution from the apo-A1 ELISA Kit, and triplicate $100-\mu 1$ serum samples were added to the same plate. Following incubation at $37^{\circ} \mathrm{C}$ for $90 \mathrm{~min}$, the supernatant in each well was removed, and biotin-conjugated anti-human Apo A-I antibody $(100 \mu \mathrm{l})$ was added, followed by incubation at $37^{\circ} \mathrm{C}$ for $60 \mathrm{~min}$. After washing, $\mathrm{ABC}$ working solution was added for visualization and the samples were incubated at $37^{\circ} \mathrm{C}$ for $30 \mathrm{~min}$. The samples were washed, 3,3',5,5'-tetramethylbenzidine $(90 \mu \mathrm{l})$ was added to each well, and stop solution $(100 \mu \mathrm{l})$ was added. The optical density was measured at $450 \mathrm{~nm}$, and a standard curve was generated. The concentration of each sample was calculated according to the standard curve.
Statistical analysis. To distinguish between the differentially expressed proteins in the serum, as screened by MS, a nonlinear support vector machine (SVM) classifier was used as previously described (19). It was originally developed by Vladimir Vapnik, with a radialbased function kernel, a parameter $\gamma$ of 0.6 , and a cost of the constrain violation of 19 . The leave-one-out crossing validation approach was applied to estimate the accuracy of this classifier (19). The capability of each peak in distinguishing data of different groups was estimated by the P-value of the Wilcoxon t-test. $\mathrm{P} \leq 0.01$ was considered to indicate a statistically significant difference.

In confirming the Apo A-I expression by qPCR and ELISA, statistical analyses were performed using SPSS software, version 17.0 (SPSS, Inc., Chicago, IL, USA). The independent samples t-test was used to compare mean values between two groups, and $\mathrm{P}<0.05$ was considered to indicate a statistically significant difference for all analyses.

\section{Results}

Screening of proteins differentially expressed between children with hepatoblastoma and healthy controls. The data collected following MS from children with hepatoblastoma and healthy controls were standardized and the protein peaks and corresponding $\mathrm{m} / \mathrm{z}$ values were compared using the Wilcoxon rank sum test. A total of 10 peaks with differences were identified $(\mathrm{P}<0.01)$. The results demonstrated that 4 highly expressed proteins and 6 proteins with low expression were identified in the serum of children with hepatoblastoma. Following screening with the SVM, a combined model with the highest Youden index was screened, and a protein with an $\mathrm{m} / \mathrm{z}$ of 9,348 Da was identified as a marker. The Youden index is a method which evaluates the reliability of the screening test. Assuming that the false negative (the missed diagnosis) 

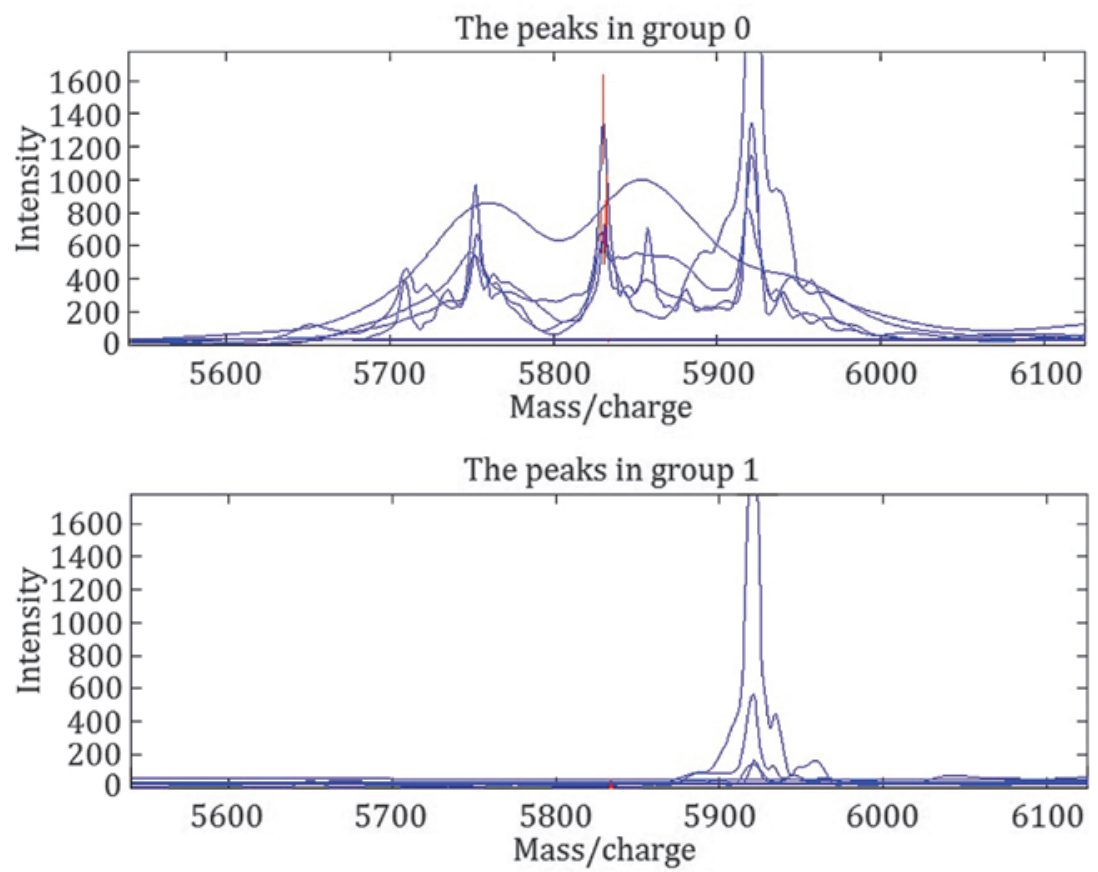

Figure 2. Screening of proteins differentially expressed between children with SIRS and healthy controls. A protein with an $\mathrm{m} / \mathrm{z}$ of $5,833 \mathrm{Da}$ demonstrated increased expression in children with SIRS compared with healthy controls $(1,283.0 \pm 943.3$ vs. $75.7 \pm 75.1$, respectively; P<0.01). Group 0, SIRS group; group 1 , the healthy control group. SIRS, systemic inflammatory response syndrome.

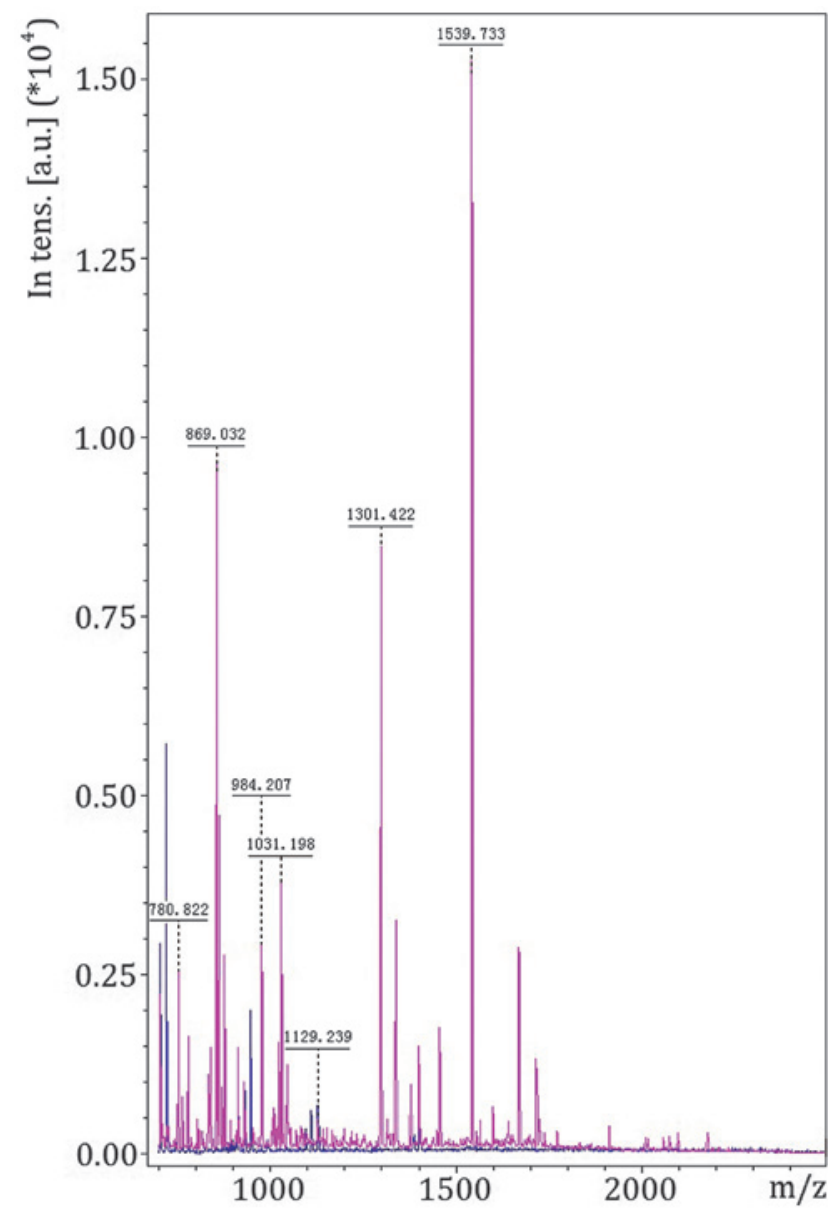

Figure 3. MS of peptides yielded by digestion of the 9,348 Da protein identified by MALDI-TOF-MS. MS of the peptide segments obtained following enzymatic digestion of the proteins and peptide segments with $\mathrm{m} / \mathrm{z}$ of 9,348 Da. MS, mass spectrometry; MALDI-TOF-MS, matrix-assisted laser desorption/ionization-time of flight-MS. and the false positives (the misdiagnosis) result in the same outcome, the Youden index may be used. The Youden index is the sum of the sensitivity and specificity minus 1 , and in this contexts refers to the total capacity of the screening method in identifying the difference between the real patients and the false negative and positives. The greater the Youdenindex value, the larger and more significant the effect and the accuracy of the screening experiment (20). As presented in Fig. 1, the expression of this protein was significantly reduced in children with hepatoblastoma compared with healthy controls (29.0 \pm 20.9 vs. $2,036.7 \pm 881.5$, respectively; $\mathrm{P}<0.01)$.

Screening of proteins differentially expressed between children with SIRS and healthy controls. Following processing and statistical analysis of data collected following MS, 10 protein peaks were identified that differed significantly $(\mathrm{P}<0.01)$ between children with SIRS and healthy controls. The results indicated 6 proteins with increased expression and 4 proteins with reduced expression compared with controls in the serum of children with SIRS. Following SVM screening, a combined model with the highest Louden index was screened, and a protein with $\mathrm{m} / \mathrm{z}$ of $5,833 \mathrm{Da}$ was identified. As presented in Fig. 2, the expression of this protein was significantly increased in children with SIRS compared with healthy controls $(1,283.0 \pm 943.3$ vs. $75.7 \pm 75.1$, respectively; $\mathrm{P}<0.01)$.

Exclusion of interfering inflammatory factors. SELDI-TOF-MS was performed to identify protein peaks that differed between children with hepatoblastoma and healthy controls, and between children with SIRS and healthy controls. Paired comparison indicated that one protein with an $\mathrm{m} / \mathrm{z}$ of 9,348 was not observed in the serum of children with SIRS (range, $\pm 0.3 \%$ ), indicating that this protein was a serum biomarker for hepatoblastoma. 
Table I. Amino acid sequence of each peptide yielded by protein digestion as determined by matrix-assisted laser desorption/ionization-time of flight-mass spectrometry.

\begin{tabular}{|c|c|c|c|}
\hline $\mathrm{M} / \mathrm{Z}$ & Protein & Peptides identified & Sequence \\
\hline \multirow[t]{7}{*}{9,348} & Apolipoprotein A-I & K.WQEEMELYRQK.V & KWQEEMELYRQKVEPLRAE \\
\hline & & R.QKVEPLR.A & LQEGARQKLHELQEKLSPLGE \\
\hline & & R.AELQEGARQK.L & EMRDRARAHVDALRTHLAPY \\
\hline & & K.LSPLGEEMR.D & SDELRQRLAARLEALKENG \\
\hline & & R.AHVDALR.T & \\
\hline & & R.THLAPYSDELR.Q & \\
\hline & & R.LAARLEALK.E & \\
\hline
\end{tabular}

$\mathrm{M} / \mathrm{Z}$, mass to charge ratio.

Table II. Amino acid sequence of the full-length protein obtained by matching and recombination of peptides.

\begin{tabular}{|c|c|c|c|c|}
\hline $\mathrm{M} / \mathrm{Z}$ & Protein & Confirmed peptide & Coverage rate $(\%)$ & Score \\
\hline 9,348 & Apolipoprotein A-I & $\begin{array}{l}\text { KWQEEMELYRQKVEPLRA } \\
\text { ELQEGARQKLHELQEKLS } \\
\text { PLGEEMRDRARAHVDAL } \\
\text { RTHLAPYSDELRQRLAAR } \\
\text { LEALKENG }\end{array}$ & 45.0 & 88 \\
\hline
\end{tabular}

$\mathrm{M} / \mathrm{Z}$, mass to charge ratio.

A

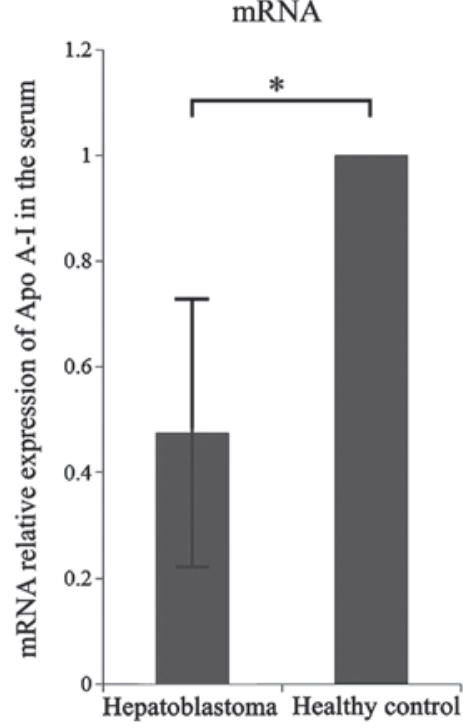

B

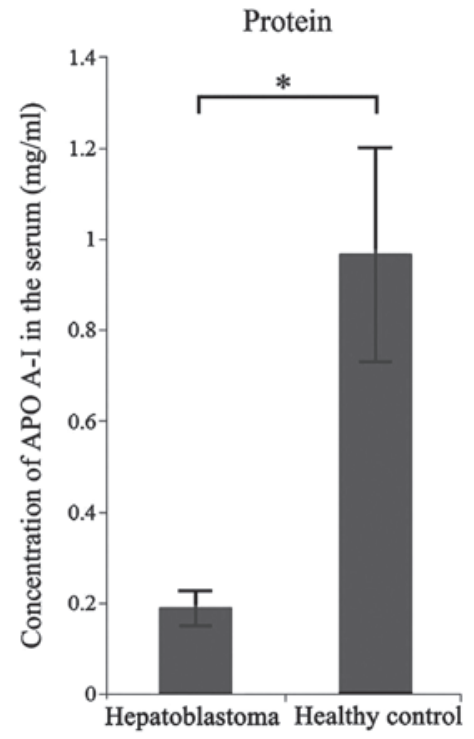

Figure 4. Apo A-I mRNA and protein expression in the serum of children with hepatoblastoma and healthy controls assessed by reverse transcription-quantitative polymerase chain reaction and ELISA. (A) The $\Delta \Delta \mathrm{Ct}$ method was used to calculate the expression level of Apo A-I mRNA, with the expression of the Apo A-I mRNA of the healthy control group defined as 1. The relative expression of Apo A-I of the hepatoblastoma group was $0.4744 \pm 0.2530$; "P $<0.05$ vs. the healthy control group. (B) A standard curve was constructed using standard samples at different concentrations and the concentration of Apo A-I protein in the serum of children with hepatoblastoma and healthy children was calculated according to the standard curve. The Apo A-I concentration was $0.1898 \pm 0.0387 \mathrm{mg} / \mathrm{ml}$ in children with hepatoblastoma and $0.9707 \pm 0.2372 \mathrm{mg} / \mathrm{ml}$ in healthy controls (" $\mathrm{P}<0.05 \mathrm{vs.}$. healthy control group).

Target protein identification. Following gel electrophoresis, the target protein with an $\mathrm{m} / \mathrm{z}$ of 9,348 Da was harvested. The protein band corresponding to the protein peak was collected and treated using in-gel digestion. MALDI-TOF-MS was 
used for MS of peptides following digestion (Fig. 3), and the amino acid sequences were determined (Table I). The peptide sequences were analyzed for matching and recombination to generate the amino acid sequence of the complete protein (Table II). Mascot searching software was used to search for a corresponding protein in the SwissProt database, revealing a protein with an $\mathrm{m} / \mathrm{z}$ of $9,348 \mathrm{Da}$ and a coverage rate of $45.0 \%$; the match score with Apo A-I was 88 .

Confirmation of Apo A-I expression by qPCR and ELISA. To confirm that the protein identified by MALDI-TOF-MS was Apo A-I, fluorescence qPCR was performed to detect Apo A-I mRNA expression in serum. The results demonstrated that Apo A-I mRNA expression levels were significantly reduced in children with hepatoblastoma compared with healthy children ( $\mathrm{P}<0.05$; Fig. 4A).

In addition, ELISA was employed to detect the levels of Apo A-I protein in the serum of children with hepatoblastoma and healthy children. A standard curve was constructed using standard samples at different concentrations, and the concentration of Apo A-I in the serum of children with hepatoblastoma and healthy children was calculated according to the standard curve. The Apo A-I concentration was significantly reduced in children with hepatoblastoma compared with healthy controls $(0.1898 \pm 0.0387$ vs. $0.9707 \pm 0.2372 \mathrm{mg} / \mathrm{ml}$, respectively; $\mathrm{P}<0.05$; Fig. 4B).

\section{Discussion}

In the present study, SELDI-TOF-MS revealed a protein with an $\mathrm{m} / \mathrm{z}$ of 9,348 Da that was expressed at significantly reduced levels in the serum of children with hepatoblastoma compared with healthy controls $(\mathrm{P}<0.01)$; the interference of inflammatory proteins in this result was excluded. Sequence analysis identified this protein as Apo A-I. qPCR and ELISA demonstrated that the expression levels of Apo A-I mRNA and protein were significantly reduced in children with hepatoblastoma compared with healthy controls $(\mathrm{P}<0.05)$. Collectively, these findings indicate that Apo A-I is a potential biomarker for hepatoblastoma.

A variety of inflammatory factors and proteins are important in the occurrence and development of malignancies, and their expression may further augment the inflammatory response. The association between inflammation and malignancies is therefore complex $(21,22)$. Inflammatory proteins may confound the identification of markers that are solely specific to tumors (18). Previous studies have demonstrated that high serum levels of IL-10, IL-1, IL-6, and TNF- $\alpha$ are closely associated with renal, colon and oral cancer (23-25). To overcome the influence of inflammatory proteins in the search for biomarkers specific to hepatoblastoma, the present study identified a differentially expressed protein with $\mathrm{m} / \mathrm{z}$ of 5,833 Da that was associated with inflammation by comparative screening of healthy controls and children with SIRS. This protein was different to the protein with an $\mathrm{m} / \mathrm{z}$ of $9,348 \mathrm{Da}$ that was identified to be differentially expressed between hepatoblastoma and healthy controls. The protein with an $\mathrm{m} / \mathrm{z}$ of 5,833 Da identified in this screening was then eliminated as an interfering factor, and the aim was to identify a biomarker of hepatoblastoma that is not associated with inflammation.
SELDI-TOF-MS analysis demonstrated that the Apo A-I protein was expressed at significantly reduced levels in the serum of children with hepatoblastoma compared with healthy controls. Since this protein was not eliminated in the SIRS inflammatory protein screening, this protein may be considered to be a specific marker for hepatoblastoma. Apo A-I is an important structural protein in the high-density lipoprotein family, and the most abundant member of the Apo A family. This $28 \mathrm{kDa}, 243$-amino-acid protein is predominantly synthesized in the liver but is expressed in the majority of tissues (26). Apo A-I is involved in several steps of lipid metabolism, stabilization of lipoprotein structure and the regulation of lipoprotein metabolism (27). Abnormalities in the structure or concentration of Apo A-I can lead to lipid metabolism disorders and induce pathological changes, including hypertension and insulin resistance $(28,29)$.

An association between Apo A-I and malignancies has been reported: A previous study demonstrated that Apo A-I is a serum biomarker specific for early-stage ovarian cancer that can be used for diagnosis (32). In order to study Apo A-I function further, 18 amino-acid peptides (Apo A-I mimetic peptides) have been designed (31). These peptides are of different subtypes $(2 \mathrm{~F}, 3 \mathrm{~F}, 4 \mathrm{~F}, 5 \mathrm{~F}, 6 \mathrm{~F}$ and $7 \mathrm{~F})$; all have helical structures similar to that of Apo A-I and anti-oxidative and hydrophilic properties. Gao et al (32) demonstrated that Apo A-I mimetic peptide L-4F regulates hypoxia inducible factor-1 $\alpha$ expression to inhibit the expression of vascular endothelial cell growth factor and angiogenesis in a number of different types of cancer. L-4F also induces the apoptosis of ovarian cancer cells, exerting antitumor effects on ovarian cancer (32). The expression of Apo A-I in early stage ovarian cancer does not preclude the use of Apo A-I as a specific biomarker for the early diagnosis of hepatoblastoma in children as ovarian cancer does not occur in preschool children.

In conclusion, the present study demonstrates that Apo A-I expression is reduced in children with hepatoblastoma compared with healthy controls. These findings indicate that Apo A-I may be used as a serum biomarker for hepatoblastoma in children. Additional studies are required to determine the actual efficacy of Apo A-I as a biomarker in clinical practice. Studies with a large patient cohort are required to determine the specificity and sensitivity of Apo A-I in diagnosing hepatoblastoma in children, and to identify any advantages of Apo A-I over other diagnostic tools. In addition, the association between Apo A-I and the occurrence and development of hepatoblastoma should be investigated to determine the role of Apo A-I in the pathogenesis of hepatoblastoma.

\section{Acknowledgements}

The present study was conducted within the Department of Pediatric Surgery, supported by the First Affiliated Hospital of Zhengzhou University. The authors thank the personnel of the Institute of Cancer, The Second Affiliated Hospital, College of Medicine of Zhejiang University (Hangzhou, China) for their excellent assistance. The study was financially supported by the National Natural Science Foundation of China (grant no. 81172085$)$. The authors would also like to thank all the patients who participated. 


\section{References}

1. Zynger DL, Gupta A, Luan C, Chou PM, Yang GY and Yang XJ: Expression of glypican 3 in hepatoblastoma: an immunohistochemical study of 65 cases. Hum Pathol 39: 224-230, 2008.

2. Ismail H, Broniszczak D, Kaliciński P, Dembowska-Bagińska B Perek D, Teisseyre J, Kluge P, Kościesza A, Lembas A and Markiewicz M: Changing treatment and outcome of children with hepatoblastoma: analysis of a single center experience over the last 20 years. J Pediatr Surg 47: 1331-1339, 2012.

3. Baertschiger RM, Ozsahin H, Rougemont AL, et al: Cure of multifocal panhepatic hepatoblastoma: is liver transplantation always necessary? J Pediatr Surg 45: 1030-1036, 2010.

4. Pan FS, Xu M, Wang W, Zhou LY and Xie XY: Infantile hepatic hemangioendothelioma in comparison with hepatoblastoma in children: clinical and ultrasound features. Hepat Mon 13: e11103, 2013

5. Alvarez-Chaver P, Otero-Estévez O, Páez de la Cadena M, Rodríguez-Berrocal FJ and Martínez-Zorzano VS: Proteomics for discovery of candidate colorectal cancer biomarkers. World J Gastroenterol 20: 3804-3824, 2014.

6. Silberring J and Ciborowski P: Biomarker discovery and clinical proteomics. Trends Analyt Chem 29: 128-140, 2010.

7. Maurya P, Meleady P, Dowling P and Clynes M: Proteomic approaches for serum biomarker discovery in cancer. Anticancer Res 27 (3A): 1247-1255, 2007

8. de Wit M, Fijneman RJ, Verheul HM, Meijer GA and Jimenez CR: Proteomics in colorectal cancer translational research: biomarker discovery for clinical applications. Clin Biochem 46: 466-479, 2013.

9. Humphries JM, Penno MA, Weiland F, et al: Identification and validation of novel candidate protein biomarkers for the detection of human gastric cancer. Biochim Biophys Acta 1844: 1051-1058, 2014.

10. Zhang Q, Wang J, Dong R, Yang S and Zheng S: Identification of novel serum biomarkers in child nephroblastoma using proteomics technology. Mol Biol Rep 38: 631-638, 2011.

11. Zhang Q, Shan Y, Wang JX, Dong R, Yang SB and Zheng S: Detection of biomarkers in children with Wilms' tumor using proteinchip technology. Chin Med J (Engl) 123: 1939-1941, 2010.

12. Wang J, Wang L, Zhang D, Fan Y, Jia Z, Qin P, Yu J, Zheng S and Yang F: Identification of potential serum biomarkers for Wilms tumor after excluding confounding effects of common systemic inflammatory factors. Mol Biol Rep 39: 5095-5104, 2012.

13. Wang J, Zhang X, Ge X, Guo H, Xiong G and Zhu Y: Proteomic studies of early-stage and advanced ovarian cancer patients. Gynecol Oncol 111: 111-119, 2008.

14. Skytt A, Thysell E, Stattin P, Stenman UH, Antti H and Wikström P: SELDI-TOF MS versus prostate specific antigen analysis of prospective plasma samples in a nested case-control study of prostate cancer. Int J Cancer 121: 615-620, 2007.

15. Liu D, Cao L, Yu J, Que R, Jiang W, Zhou Y and Zhu L: Diagnosis of pancreatic adenocarcinoma using protein chip technology. Pancreatology 9: 127-135, 2009.
16. Hundt S, Haug U and Brenner $\mathrm{H}$ : Blood markers for early detection of colorectal cancer: a systematic review. Cancer Epidemiol Biomarkers Prev 16: 1935-1953, 2007.

17. Gonçalves A, Bertucci F, Birnbaum D and Borg JP: Protein profiling SELDI-TOF and breast cancer: clinical potential applications. Med Sci (Paris) 23: 23-26, 2007. (In French).

18. Kelly-Spratt KS, Pitteri SJ, Gurley KE, et al: Plasma proteome profiles associated with inflammation, angiogenesis, and cancer. PLoS One 6: e19721, 2011.

19. Fan Y, Shi L, Liu Q, et al: Discovery and identification of potential biomarkers of papillary thyroid carcinoma. Mol Cancer 8: 79, 2009.

20. Xu T, Wang J and Fang Y. A model-free estimation for the covariate-adjusted Youden index and its associated cut-point. Stat Med 33: 4963-4974, 2014.

21. Chechlinska M, Kowalewska M and Nowak R: Systemic inflammation as a confounding factor in cancer biomarker discovery and validation. Nat Rev Cancer 10: 2-3, 2010.

22. Hou JM, Zhao X, Tian L, et al: Immunotherapy of tumors with recombinant adenovirus encoding macrophage inflammatory protein 3beta induces tumor-specific immune response in immunocompetent tumor-bearing mice. Acta Pharmacol Sin 30: 355-363, 2009.

23. Kondo T, Ito F, Nakazawa H, Horita S, Osaka Y and Toma H: High expression of chemokine gene as a favorable prognostic factor in renal cell carcinoma. J Urol 171: 2171-2175, 2004.

24. van Grevenstein WM, Hofland LJ, van Rossen ME, van Koetsveld PM, Jeekel J and van Eijck $\mathrm{CH}$ : Inflammatory cytokines stimulate the adhesion of colon carcinoma cells to mesothelial monolayers. Dig Dis Sci 52: 2775-2783, 2007.

25. Jablonska E, Piotrowski L and Grabowska Z: Serum Levels of IL-1 $\beta$, IL-6, TNF- $\alpha$, sTNF-RI and CRP in Patients with Oral Cavity Cancer. Pathol Oncol Res 3: 126-129, 1997.

26. Law SW, Lackner KJ, Fojo SS, Hospattankar A, Monge JC, and Brewer HB Jr: The molecular biology of human apoA-I, apoA-II, apoC-II and apoB. Adv Exp Med Biol 201: 151-162, 1986.

27. Frank PG and Marcel YL. Apolipoprotein A-I: Structure-function relationships. J Lipid Res 41: 853-872, 2000.

28. Ma YQ, Thomas GN and Tomlinson B. Association of two apolipoprotein A-I gene MspI polymorphisms with lipid and blood pressure levels. Int J Cardiol 102: 309-314, 2005.

29. Du T, Yuan G, Zhang M, Zhou X, Sun X and Yu X. Clinical usefulness of lipid ratios, visceral adiposity indicators, and the triglycerides and glucose index as risk markers of insulin resistance. Cardiovasc Diabetol 13: 146, 2014.

30. Su F, Lang J, Kumar A, et al: Validation of candidate serum ovarian cancer biomarkers for early detection. Biomark Insights 2: 369-375, 2007.

31. Getz GS, Wool GD and Reardon CA: Apoprotein A-I mimetic peptides and their potential anti-atherogenic mechanisms of action. Curr Opin Lipidol 20: 171-175, 2009.

32. Gao F, Chattopadhyay A, Navab M, et al: Apolipoprotein A-I mimetic peptides inhibitexpression and activity of hypoxia-inducible factor- $1 \alpha$ in human ovarian cancer cell lines and a mouse ovarian cancer model. J Pharmacol Exp Ther 342: 255-262, 2012. 